\title{
RESTRICTIONS ON ENTRY OF SURFACE CARRIERS SEEKING TO FLY
}

President Kennedy, in a recent message to Congress, vigorously recommended the elimination of obstacles to free competition in transportation. He pointed to the existence of distortions and inefficiencies inherent in existing federal policies, and advocated equality of opportunity for all forms of transportation and greater reliance on the forces of competition rather than the restraints of regulation. ${ }^{1}$ This Comment examines a particular obstacle to resource mobility: the legal barrier to surface carrier participation in air transportation. This restriction is found in section 408 of the Civil Aeronautics Act, ${ }^{2}$ one of the transportation statutes to which the President referred.

The Civil Aeronautics Act was enacted as part of a network of statutes regulating the various modes of transportation. ${ }^{3}$ The act vested in the Civil Aeronautics Board extensive control over the entry, rates, and ownership of commercial air carriers. ${ }^{4}$ Section 401 requires all air carriers, including passenger, cargo carriers, and air forwarders, to obtain a certificate of public convenience and necessity or an exemption before conducting air transport operations. ${ }^{\mathbb{E}}$ Subsection (e), the grandfather clause, assured certification of any applicant who established that he had continuously operated as an air carrier for a specified period prior to the passage of the act. ${ }^{B}$ All other applicants must prove, pursuant to section 401 (d), that they are "fit, willing, and able" to perform the proposed service and that such service is required by the "public convenience and necessity." This latter entry requirement had through its long use in railroad regulation acquired a reasonably definite meaning; the carrier had to show a positive need for its service, or, in other words, the inadequacy of existing services. ${ }^{8}$ The policies set out in section 2

1. See text of the President's message to Congress on transportation, N.Y. Times, April 6, 1962, p. 18, col. 2 .

2. 52 Stat. 1001 (1938), 49 U.S.C. $\$ 1378$ (1958). All textual citations of sections of the Civil Aeronautics Act and all citations of that act from the Statutes at Large will refer to Ch. 601, 52 Stat. 973-1030 (1938).

3. Motor Carrier Act of 1935, 49 Stat. 543 (1935), as amended, 49 U.S.C. $\S \S 301-27$ (1940) (trucking); Civil Aeronautics Act of 1938, 52 Stat. 973 (1938), as amended, 49 U.S.C. §§ 1301-86 (1958) (aviation) ; Transportation Act of 1940, 54 Stat. 898, 929 (1940), 49 U.S.C. $\$ \$ 901-23$ (1940) (water carriage).

4. Section 401, 52 Stat. 987 (1938), 49 U.S.C. $\$ 1371$ (1958) (entry) ; § 403, 52 Stat. 992 (1938), 49 U.S.C. § 1373 (1958) (rates); § 408, 52 Stat. 1001 (1938), 49 U.S.C. § 1378 (1958) (ownership).

5. Section 401(a), 52 Stat. 987 (1938), 49 U.S.C. § 1371(a) (1958). Section 1(2), which defines "air carrier," empowers the Board to exempt air forwarders from the provisions of the act, see notes 44-46 infra and accompanying text.

6. Section 401 (e), 52 Stat. 988 (1938), 49 U.S.C. $\$ 1371$ (e) (1958).

7. Section 401(d), 52 Stat. 987 (1938), 49 U.S.C. $\$ 1371$ (d) (1958).

8. It appeared in the Transportation Act of 1920, § 402, 41 Stat. 477 (1920), 49 U.S.C. $\S$ 1(18)-(20) (1958), and was construed in Texas \& N.O.R.R. v. Northside Belt Ry., 276 
of the act, however, have somewhat modified this traditional interpretation of "public convenience and necessity." These policies include "encouragement and development" of air transportation, its regulation in such manner "as to recognize and preserve the inherent advantages of, assure the highest degree of safety in, and faster sound economic conditions in, such transportation," "promotion of adequate, economical, and efficient service by air carriers at reasonable charges," and "competition to the extent necessary to assure the sound development" of the air industry. ${ }^{9}$ Furthermore, the restrictive proviso of section 408, designed to limit surface carrier participation in air transport, presents another factor for the Board to consider in licensing air carriers.

Section 408 requires approval of the $C A B$ for consolidations, mergers, purchases, leases, operating contracts, or acquisitions of control of two or more air carriers, an air carrier and a surface carrier, or an air carrier and a business engaged in any other phase of aeronautics, ${ }^{10}$ and it prescribes criteria for the approval of these transactions. ${ }^{11}$ Besides a general standard that the transaction be consistent with the "public interest," section 408 includes two provisos. The first proviso requires that the transaction not result in creating a monopoly or monopolies, thereby restraining competition or jeopardizing another air carrier that is not a party to the transaction. The second proviso, particularly pertinent to surface carrier ownership, states that if application is made by "a carrier other than an air carrier," the Board may deny approval unless it finds that:

the transaction proposed will promote the public interest by enabling such carrier other than an air carrier to use aircraft to public advantage in its operation and will not unduly restrain competition. ${ }^{12}$

Believing that the proviso was intended to be extremely restrictive in section 408 proceedings, the Board has held that only those air transport operations which are "auxiliary and supplementary" to surface transport services come within the purview of the "use aircraft to public advantage in its operations" requirement. ${ }^{13}$ Thus, a surface carrier acquiring control of an air carrier must show "physical integration" of the use of aircraft in its surface operations. ${ }^{14}$ The dearth of cases in which a surface carrier has successfully fulfilled this condition is understandable, since air operations are hardly physically integrated with rail, shipping, and trucking services. ${ }^{15}$ Because the restriction on

U.S. 475 (1928). For a discussion of public convenience and necessity in rail and trucking regulation, see Note, National Transportation Policy and the Regulation of Motor Carriers, 71 Y ALE L.J. 307, 309-11 (1961).

9. Section 2, 52 Stat. 980 (1938), 49 U.S.C. $\$ 1302$ (1958).

10. Section 408(a), 52 Stat. 1001 (1938), 49 U.S.C. $\$ 1378$ (a) (1958).

11. Section 408(b), 52 Stat. 1001 (1938), 49 U.S.C. $\$ 1378$ (b) (1958).

12. Section 408(b), 52 Stat. 1002 (1938), 49 U.S.C. $\$ 1378$ (b) (1958).

13. American Export Airlines, 3 C.A.B. 619, 624 (1942) (remand opinion).

14. American Export Airlines, 4 C.A.B. 104, 111 (1943) (supplemental opinion).

15. See Fulda, Competition IN Regulated Industries: Transportation $\$ \S 12.15-.16$ (1961). 
surface carrier participation in air carriage is set forth in a proviso, an application under section 408 that fails to meet the specific requirements of that proviso must be disapproved, notwithstanding that the other policies of the act would be promoted by approval of the application.

The surface carrier proviso reflects a congressional concern during the late thirties with the dangers of intermodal ownership among transportation media. In the Motor Carrier Act of 1935 Congress enacted a similar provision inhibiting railroad participation in trucking. ${ }^{16}$ This provision provided the model for the surface carrier proviso in the Civil Aeronautics Act. In fact, the CAB's construction of the surface carrier proviso to require "auxiliary and supplementary" operations was borrowed from the experience of the ICC in elaborating the similar restriction on the acquistions of motor carriers. ${ }^{17}$ Furthermore, the Transportation Act of 1940 incorporated a prohibition forbidding any railroad or other common carrier from having an interest in a water carrier operating through the Panama Canal or elsewhere "with which such carrier ... does or may compete for traffic."18

Section 408 is the only provision of the act which explicitly refers to surface carrier participation in air carriage. When a surface carrier merges with, or acquires control of, a licensed air carrier, the limiting proviso of section 408 unquestionably comes into play. But should a surface carrier or its subsidiary request operating authority under section 401, the applicability of section 408's second proviso or its policy is not clear, since the language of section 401 does not explicitly require surface carrier applicants, or applicants controlled by surface carriers, to meet special qualifications. Public convenience and necessity, as defined traditionally or in the act, does not incorporate a restriction on surface carrier participation.

16. Section 213(a) (1), 49 Stat. 556 (1935), now $\S 5$ (2) (b), 54 Stat. 906 (1940), as amended, Act of August 2, 1949, ch. 379, § 3, 63 Stat. 485 (1949), 49 U.S.C. $\S 5$ (2) (b) (1958).

17. See American Export Airlines, 3 C.A.B. 619, 624 (1942) ; see generally, Hickey, Surface Carrier Participation in Air Transportation Under the Civil Aeronautics Act, 36 Geo. L.J. 125, 144-53 (1948) ; Tomlinson, Surface Carrier Participation in Air Transportation, 34 Geo. L.J. 64, 71 (1946). But see Baggett, The Right of Steamship Carriers to Participate in Transoceanic Air Service, 12 ICC Prac. J. 3, 8-13 (1944); James, Control of One Form of Transportation by Another, 12 ICC PRAC. J. 214, 220 (1944). For a description of the "auxiliary and supplementary" standard as used by the ICC, see Special Study Group on Transportation Policies in the United States, Preliminary Draft of a Report on National Transportation Policy, 87th Cong., 1st Sess. 140-42 (Comm. print 1961). For an analysis of the ICC's elaboration of the Motor Carrier Act, see Fulda, Rail-Motor Competition: Motor-Carrier Operations by Railroads, 54 Nw. U.L. Rev. 156 (1959), and Note, National Transportation Policy and the Regulation of Motor Carriers, 71 YALE L.J. 307 (1961).

18. The prohibition was originally contained in the Panama Canal Act of 1912, ch. 390, § 11, 37 Stat. 560, 566 (1912), as amended, 49 U.S. C. \$ 5(14) (1940). See Hickey, supra note 17, at 143; Tomlinson, supra note 17, at 69-71. But see Baggett, supra note 17, at 5-8; James, supra note 17 , at $217-18$. 


\section{The Relationship of Sections 401 and 408}

A relationship between the proviso of section 408 and certification of surface carriers under section 401 was first established in the American Export case. ${ }^{10}$ American Export Airlines, a subsidiary of American Export Lines, Inc. (hereafter referred to as Steamship Company), applied for operating authority to conduct air carrier service over the North Atlantic trade route. Since American Export Airlines was a subsidiary of "a carrier other than an air carrier," the applicant also requested that the Board approve, under section 408, its control by Steamship Company, "if such approval is deemed necessary." At the time of these proceedings the only American air carrier rendering transatlantic service was Pan American Airways Company, which intervened in opposition to American Export's application. Although recognizing that the intervener had pioneered the route under consideration and that it was operating efficiently within the limits of its facilities, the Board found that there was sufficient traffic on the route to support another air carrier and that additional competition from a second United States carrier would be desirable. The Board thus concluded that the service proposed by American Export Airlines was demanded by the public convenience and necessity. ${ }^{20}$

The Board then proceeded to dispose of the application for approval under section 408. Applicant had asserted that because the acquisition of its stock by Steamship Company antedated the Civil Aeronautics Act of 1938, there was no acquisition requiring the Board's approval. Counsel for intervener and for the $\mathrm{CAB}$ insisted that a section 408 question was properly before the Board. They contended that despite the fact that the acquisition of applicant as a corporate entity occurred before passage of the act, the acquisition of an air carrier would not take place until the corporate entity became an air carrier-upon receiving a certificate and actually undertaking air transport operations. The Board enunciated its own solution to the section 408 problem in this case ; it found that section 408 applied:

to cases involving the control of air carriers only where the acquistion of control of a corporate entity occurs at a time when that entity is already an air carrier. ${ }^{21}$

Because the applicant was not an air carrier when Steamship Company acquired control, the Board dismissed the application filed under section 408.22

The Court of Appeals for the Second Circuit, in reviewing the American Export decision in Pan American Airways Co. v. CAB, ${ }^{23}$ agreed with the Board that the act does not require a surface carrier or an applicant controlled

19. 2 C.A.B. 16 (1940), rev'd in part sub nom. Pan Am. Airways Co. v. CAB, 121 F.2d 810 (2d Cir. 1941), remanded, 3 C.A.B. 619 (1942), supplenental proceeding, 4 C.A.B. 104 (1943).

20. American Export Airlines, 2 C.A.B. 16, $32-34$ (1940) (initial opinion).

21. Id. at 46 .

22. Id. at 46,47 .

23. 121 F.2d 810 (2d Cir. 1941). 
by a surface carrier to meet the standard of section 408 (b)'s second proviso as a condition precedent to receiving a certificate of public convenience and necessity in a section 401 licensing proceeding. ${ }^{24}$ But the court rejected the Board's "literal" construction of section 408, holding that the statutory language of section 408(a) - "to acquire control of any air carrier in any manner whatsoever"-includes not only the acquisition of corporate control through the purchase of stock but also the subsidiary's subsequent action of obtaining operating authority to carry on air transport services. Instead of viewing the purchase of a controlling interest in a subsidiary as one transaction and the obtaining of a certificate from the $\mathrm{CAB}$ as another, the court conceptually lumped these two occurrences together and viewed them as parts of a single transaction. Any other interpretation, the court concluded, would enable a surface carrier to escape the requirements of the second proviso of section 408 (b) merely by organizing a subsidiary for air carriage. ${ }^{25}$

On remand, ${ }^{26}$ the $\mathrm{CAB}$ found that the relationship between Steamship Company and its air carrier subsidiary failed to meet the requirement of the second proviso in spite of American Export's contention that the two companies would be able to achieve substantial economies by coordinating communication, meteorological and navigation facilities, and traffic and other operating functions. The Board asserted that a showing on any or all of these points would be insufficient, since the proposed air services would nevertheless fail to be "auxiliary and supplementary" to Steamship Company's surface operations. Consequently, Steamship Company was ordered to divest itself of control of American Export Airlines. ${ }^{27}$ The Board's remand opinion also contained significant dicta with regard to the applicability of the second proviso of section 408 (b) in a section 401 certification proceeding. Since it is unreasonable to distinguish between entry of a surface carrier's subsidiary and entry of the surface carrier itself, and since the court found that Congress intended the second proviso to apply directly in the former case, the Board announced that it would treat the policy of the second proviso as controlling in all section 401 licensing proceedings. ${ }^{28}$

Although this conclusion seems sound, given the holding of the court in Pan American, the court's treatment of an acquisition of a paper subsidiary as it would an acquisition of an operating air carrier is questionable. For there

\footnotetext{
24. Id. at $815-16$.

25. Id. at 815 .

26. American Export Airlines, 3 C.A.B. 619 (1942) (remand opinion), 4 C.A.B. 106 (1943) (supplemental opinion).

27. 4 C.A.B. at 112. The divestiture order was met by a transfer of control to American Airlines. Steamship Company retained its stock ownership in American Export Airlines while American Airlines purchased authorized but theretofore unissued stock of the latter corporation. The transaction gave American Airlines $51.4 \%$ of applicant's issued and outstanding stock. The CAB granted its approval of this transaction in American Airlines, 6 C.A.B. 371 (1945).

28. 3 C.A.B. at 625. The Board's dicta was contrary to the holding of the Second Circuit on this issue. See note 24 supra and accompanying text.
} 
is no functional difference between entry by a surface carrier in its own name and by a surface carrier through its subsidiary. In the former case, only section 401 is applicable, and the court held that section 408 (b)'s second proviso was not a controlling standard in this type of certification proceeding, ${ }^{20}$ while in the latter case the court held that the standards of the second proviso were to be literally applied. ${ }^{30}$

On the other hand, the decision of the Board in the first American Export case, based upon the express terms of the two sections of the act, does seem supportable. The differentiation in the act of entry of a surface carrier or a surface carrier subsidiary and surface carrier acquisition of a licensed air carrier rests upon a distinction between buying-into and building-into an air transport market. Since American Export acquired a paper subsidiary, rather than an operating air carrier, and actually established and developed new air transport services, ${ }^{31}$ it was obviously diversifying by expansion rather than by merger. Congress may have required that "buying in" be subject to different standards than "building in," since the latter transaction provides the market with a new competitor while the former merely involves the change of control of an existing competitor. ${ }^{32}$ The fact that section 401 does not impose special requirements upon surface carriers applying for certificates of public convenience and necessity-and section 408 requires surface carriers seeking approval of "acquisition of control" over air carriers to meet special standardssuggests that Congress was less concerned with surface carrier expansion than with surface carrier acquisition. ${ }^{33}$

29. Pan American Airways Co. v. CAB, 121 F.2d 810, 815-16 (2d Cir. 1941).

30. See note 25 supra and accompanying text.

31. An essential step in the creation of a subsidiary is, at some point, the parent corporation's giving the new corporation assets in exchange for a controlling interest in it, and in this sense it is accurate to speak of the "acquisition" of a paper subsidiary. For a description of American Export's plans for development of air operations, see 2 C.A.B. at 35-42.

32. A firm seeking to enter a new market will most likely find it easier to buy into it rather than to build into it. The following advantages to the firm of buying over building have been suggested: (1) New facilities can be purchased more quickly than they can be built. (2) Since securities of the acquired firm are frequently selling below the replacement cost of its assets, it is often cheaper to buy. (3) The purchase of another firm may bring specialized know-how or managerial ability (though in reality this is but a variant of the proceeding point since talent of this sort presumably could be "bought" at some price). (4) Buying an existing firm provides a certain security, in that it may assure the acquiring firm of products or services that have already proved themselves in the market. (5) An acquisition can sometimes be financed nore easily than new construction, since stockholders of the acquired firm may be more willing to accept shares of the acquiring company than investors would be to take such shares at a public distribution. Bok, Section 7 of the Clayton Act and the Merging of Law and Economics, 74 HARV. L. REv. 226, 302-03 (1960).

33. In its remand opinion, 3 C.A.B. 619 (1942), the Board hinted that it had the building-buying distinction in mind when, in its first American Export opinion, 2 C.A.B. 16 (1940), it dismissed the $\$ 408$ application. It remarked:

The Board construed the provisions [of $\S 408$ ] as applying only to the acquisitions of air carriers actually engaged in air transportation and as not therefore applying to subsidiaries created for the purpose of initally developing an air transportation enter- 
The creeping control doctrine of the Pan American case did not affect those surface owned air carriers who were conducting air transport operations prior to the effective date of the act. ${ }^{34}$ When the Board was faced with an air carrier holding a "grandfather" certificate in Railroad Control of Northeast Airlines, ${ }^{35}$ it held section 408 inapplicable since the applicants had not acquired control of the airline subsequent to the enactment of the Civil Aeronautics Act. The CAB made no mention of the grandfather clause, but observed that Congress must have been aware of surface carrier control at the time the act was passed, pointed to the prospective nature of the language of section 408, and noted the traditional disfavor of courts toward interpretations giving retroactive effect to legislation. The control relationship in American Export had also been effected prior to the enactment of the Civil Aeronautics Act; American Export pointed to this fact in support of its contention that no question arose under section 408. The American Export case is distinguishable, however, from Railroad Control of Northeast Airlines, since American Export involved the post-enactment increase of surface carrier control over an air carrier; only after the effective date of the act did the surface carrier subsidiary become an air carrier. ${ }^{36}$ Thus, the control of American Export Airlines by Steamship Company did not involve substantial pre-enactment investment to the extent of full-blown operations in air carriage, as did the railroad's control in Northeast. This distinction seems to furnish a functional basis for the Board's regarding section 408 as

prise. Under such a construction, it logically would follow that the Board would conclude that Congress in enacting the Act could not have regarded as necessarily inconsistent with the public interest the entrance into the air transportation field of carriers engaged in other forms of transportation where such an entry was accomplished by the initial establishment and development of new air transport services.

3 C.A.B. at 625.

34. Two pre-enactment control relationships which have found their way into antitrust litigation are the ownership of Hawaiian Airlines by Inter-Island Steam Nav. Co., Hawaiian Airlines v. Trans-Pac. Airlines, 78 F. Supp. 1 (D. Hawaii 1948) ; United States v. InterIsland Steam Nav. Co., 87 F. Supp. 1010 (D. Hawaii 1950); and the half ownership of Pan Am.- Grace Airways ("Panagra") by W. R. Grace \& Co. (the other half owner being Pan Am. World Airways), United States v. Pan Am. World Airways, 193 F. Supp. 18 (S.D.N.Y. 1961), prob. juris. noted, 368 U.S. 966 (1962).

35. 4 C.A.B. 379 (1943). The CAB proceeding was occasioned by a refinancing in 1940 which resulted in a reduction of the equity holdings of the Boston and Maine Railroad and of the Maine Central Railroad in Northeast Airlines. 4 C.A.B. at 383. The railroads were apprehensive that the refinancing might be considered an "acquisition of control" within the meaning of $\S 408$, and thus requested a Board decision to the effect that either the section was inapplicable or, if applicable, that its provisions were not violated. Id. at 380 . Northeast Airlines, which until the 1940 transaction was named Boston-Maine Airways, had been organized by the two railroads in 1931. Id. at 382 .

36. At the time of the initial proceeding, 2 C.A.B. 16 (1940), American Export Airlines had made only survey flights. Id. at 39-40. The Board later granted it a certificate permitting temporary service between New York and Foynes, Ireland. 3 C.A.B. 294 (1941). Pursuant to this certificate, American Export Airlines commenced operations on June 20, 1942. 3 C.A.B. 619, 621 (1942). 
"prospective only" in Northeast, while seeming to give it retroactive effect in American Export. ${ }^{37}$

The position taken in the remand opinion of American Export that section 408(b)'s second proviso applies as a controlling standard in all section 401 proceedings was soon overruled in American President Lines. ${ }^{38}$ Noting that section 401 contains no language restricting surface carrier entry, the Board held that a surface carrier, applying for a certificate in its own name, rather than through a subsidiary, which would trigger section 408 under the Pan American doctrine, need not comply with the second proviso as "a legal condition" to being certificated.

Had Congress intended such compliance to be a legal condition to certification, the Board reasoned, it would have included a surface carrier restriction either in section 401 or in section 2's enumeration of factors to be considered in determining the "public convenience and necessity." The Board believed, however, that section 408(b)'s second proviso should be treated as a "statutory standard," explaining:

There is a significant difference between a legal condition to Board action and a statutory standard to be considered in reaching a judgment. The former is rigid in its requirement and leaves the Board no discretion as to its application; the latter is a guide which, with other appropriate standards, lights the way to a judgment based on sound discretion. ${ }^{30}$

The Board pointed out that this interpretation of the interrelationship of sections 401 and 408 was in conformity with the ICC experience in regulating railroad entry into trucking under the Motor Carrier Act. ${ }^{40}$

37. The Board may be able to bring the policies ascribed to $\S 408$ (b)'s second proviso to bear on surface carrier control of a grandfather certificated airline under $\S 401(\mathrm{~h}), 52$ Stat. 989 (1938), 49 U.S.C. $\$ 1371$ (g) (1960) (authority to modify, suspend, or revoke certificates). In Hawaiian Airlines v. Trans-Pac. Airlines, 78 F. Supp. 1 (D. Hawaii 1948), defendent alleged, in a cross-complaint, that the control of plaintiff by Inter-Island Steam Nav. Co. violated the antitrust laws. Plaintiff defended against this charge by contending that the $C A B$ had "primary jurisdiction" over this issue because the Board could attack its preenactment control relationship under $\$ 401(\mathrm{~h})$ and, in that manner, apply the policies behind $\S 408$ (b)'s second proviso to it. $I d$. at 4 . The district judge, in denying that the Board had "primary jurisdiction," commented :

To say as defendants [on the cross-complaint] do that it [the CAB] could threaten Hawaiian with suspension of its certificate unless Inter-Island did what the Board might say should be done, does not impress me as either plausible or practical. Agencies no more than courts waste their efforts on useless orders. If the threat Id. at 9. should be executed its lawfulness would be litigated while the public stood stranded.

38. 7 C.A.B. 799 (1947). This case arose from a petition filed by nine steamship lines requesting a general investigation of one aspect of surface carrier air participation. The decision, rejecting the request, is in the nature of a declaratory judgment on the relationship of $\S \S 401$ and 408 . For an excellent presentation of the position taken by various CAB members in this case, see Comment, Participation of Steamship Companies in Air Transportation, 34 CORNELL L.Q. 588 (1949).

39. 7 C.A.B. at 802 .

40. Id. at 804-07. For a description of the ICC experience, see Fulda, stpra note 17, at $180-97$. 
The discretionary treatment of section 408 in entry proceedings was not, however, extended to those situations in which the applicant for a certificate is a subsidiary of a surface carrier. Although Parks Investigation Case ${ }^{41}$ suggests that the second proviso is not controlling in entry of a surface carrier subsidiary, the Board held, in accordance with the Pan American doctrine, that the grant of a certificate would automatically trigger section 408 . This fact was sufficient reason for the denial of a certificate. ${ }^{42}$ Moreover, in the Southeastern Area Local Service case, ${ }^{43}$ decided in 1957, the Board denied a certificate to Southeast Airlines, which was wholly owned by Mason and Dixon Lines, a common carrier of freight by motor truck. This parentage, the Board observed, would bar the award of a certificate to Southeast unless certification were conditioned upon prior divestment of control by the parent company. But the Board noted that Southeast was so intertwined with Mason and Dixon Lines in matters of financing, facilities, and managerial talent that, were the airline divested from its surface carrier parent, the applicant's fitness and ability would be vitiated. Thus Southeast was condemned by operation of the second proviso of section 408 (b) if it retained its surface parentage and condemned by operation of the fitness and ability test of section 401 (d) if it became a corporate orphan.

The Board apparently did not appreciate the implications if its American President Lines holding that the surface carrier proviso would be treated as a "statutory standard" rather than as a "legal condition" in section 401 proceedings. It seemed to regard the approach announced there as discretionary only in the sense that the presumption raised against surface carrier entry by the applicant's failure to show that the proposed service would be "auxiliary and sup-

41. 11 C.A.B. 779 (1950), aff'd sub nom. Continental Southern Lines v. CAB, 197 F.2d 397 (D.C. Cir. 1951), cert. denied, 344 U.S. 831 (1952).

42. Continental Southern Lines, a bus company, had applied in its own name for certificates of public convenience and necessity, but during the proceedings, Continental Southern contracted to sell all its stock to Transcontinental Bus Company, an operating and holding company likewise engaged in motor carriage. Thus, Continental Southern, although itself a surface carrier applying in its own name for certification, became the subsidiary of a surface carrier with the result that should a certificate be granted to it, $\S$ 408 would be brought into play. Nonetheless the two bus companies urged the CAB to certificate Continental Southern. The Board saw two problems which would arise were it to certificate Southern Continental and then find in a subsequent $\$ 408$ proceeding that the bus companies were unable to satisfy the terms of the second proviso. First, it observed:

If this should be the result of the 408 case, we would then be legally required to order Transcontinental to divest itself of control of Continental Southern. There is no assurance that Transcontinental would take this action. If it did not, and preferred to retain its control of Continental Southern purely as a bus operation, our action in certificating Continental Southern in this proceeding would have been futile.

11 C.A.B. at 788. In addition, the Board noted that it lacked assurance that the bus companies would be willing to make the substantial investments necessary for immediate activation of the routes involved in this case pending the outcome of a $\$ 408$ proceeding. Ibid.

43. Docket No. 7038 (CAB Sept. 29, 1958), aff'd sub nom. Southeastern Aviation, Inc. v. CAB, 283 F.2d 189 (D.C. Cir. 1960). 
plementary" could be overcome by a showing that the service was "required" by the "public interest." But since "auxiliary and supplementary" air carriage, unlike rail owned motor carrier service, is not feasible, the Board would almost invariably find that the surface carrier applicant had failed to meet its integrality test of section 408 (b)'s second proviso. Thus, in every surface carrier entry case, the $\mathrm{CAB}$ would have to weigh the effect of the entrant's noncompliance with the proviso against the public convenience and necessity of the proposed air service. But the balance is incomplete without a consideration not of the lack of "auxiliary and supplementary" services but of the reasons for inhibiting surface carrier participation in air transportation. This discretionary judgment thus necessitates a departure from the literal terms of the proviso to an examination of the policy believed to be embodied therein. The Board's mention in American President Lines of the dangers that Congress might have had in mind when it enacted the restrictive proviso indicates the Board's awareness of this additional factor which a full determination of the public interest entails. Indeed, in those cases in which the $\mathrm{CAB}$ has viewed section 408 as a discretionary guide instead of a legal condition, it has not considered the express terms of the proviso at all, but the policy behind it.

An examination of situations where indirect air carriers controlled by railroad, trucking, and shipping companies have applied for operating authority indicates the manner in which the Board treats the second proviso of section 408 (b) when it is weighed as one of several factors relevant to a determination of the propriety of entry rather than as a per se bar to entry. Subsequent analysis will consider the possibility and advisability of applying the discretionary standards of the forwarder cases to the entry applications of both surface carriers and surface carrier subsidiaries.

\section{The Experience in Indirect Air Carriage}

Section 1(2) of the Civil Aeronautics Act defines air carrier to mean any company which engages, directly or indirectly, in air transportation and provides that the Board may exempt air carriers not directly engaged in the operation of aircraft from the provisions of the act. ${ }^{44}$ An indirect carrier-the type referred to in the exemption clause of section 1(2)-operates no aircraft. Rather it, hereafter called an air forwarder, collects and consolidates cargo from various shippers and transfers such cargo to an airline and receives shipments at the terminal airport, "breaks bulk," and distributes the shipment's components to the ultimate consignees. The forwarder takes advantage of the lower rates for large volume shipments and, to some extent, passes this advantage along to its customers, who individually lack sufficient volume to any

44. 52 Stat. 977 (1938), 49 U.S.C. \& 1301(3) (1958). Section 1(2) reads:

"Air carrier" means any citizen of the United States who undertakes, whether direct$1 \mathrm{y}$ or indirectly or by a lease or any other arrangement, to engage in air transportation: Provided, That the Authority may by order relieve air carriers who are not directly engaged in the operation of aircraft in air transportation from the provisions of this chapter to the extent and for such periods as may be in the public interest. 
particular destination to qualify for these lower rates. An indirect carrier may also perform various traffic management ${ }^{45}$ functions for the shipper. Apparently because of the lack of experience with air forwarders in 1938, ${ }^{46}$ Congress provided that the Board may exempt such carriers from the terms of the act.

In an early forwarder entry proceeding, the Board granted a temporary exemption without reference to the fact of surface carrier control. ${ }^{47}$ Railway Express Agency, the first forwarder applicant, had engaged in "air express" forwarding under contracts with substantially all domestic air carriers and sought authorization under the grandfather clause to continue its operations. Although the grandfather provision instructed the $\mathrm{CAB}$ to grant a certificate upon a showing that the applicant was an air carrier, continuously operating, during a specified pre-enactment period, the Board, believing that the language of section 401 (e) only contemplated actual air operations, concluded that this clause neither required nor authorized the issuance of a grandfather certificate to indirect carriers. ${ }^{48}$ It did find, however, that a grant of a temporary exemption

45. See Air Freight Forwarder Case, 9 C.A.B. 473, 490-92 (1948); Emery, The Freight Forwarder and the Development of Air Freight, 15 LAw \& ContenrP. ProB. 29, 30-33 (1950).

46. Prior to 1948, only Railway Express Agency was engaged in indirect air carriage. See Railway Express Agency, 2 C.A.B. 531 (1941); Air Freight Forwarder Case, 9 C.A.B. 473, 491 (1948).

47. Railway Express Agency, 2 C.A.B. 531 (1941). REA's authorized capital consisted of 1000 shares of no-par value stock, of which all but six shares were owned by railroads, as indicated in Air Freight Forwarder Case, 9 C.A.B. 473, 478 (1948). The six shares were held by Canadian National Realities, Itd., in trust. Ibid.

48. The CAB pointed out that the certificate issued pursuant to the grandfather clause authorized its recipient to engage in air transportation "between the terminal and intermediate points during which it ... so continuously operated" during the grandfather period. 2 C.A.B. at 539. The Board reasoned that by referring to operations "between terminal and intermediate points" the clause contemplated physical operations conducted directly by an applicant between such points. Id. at 540. As REA's activities had not included the physical operation of aircraft between terminal and intermediate points, the CAB surmised that the language of $\S 401$ (e) could not be said to include within its scope REA's activities. Ibid. The Board observed further that a certificate issuing under $\$ 401$ (e) must authorize the applicant to engage in air transportation "with respect to all classes of traffic for which the authorization is sought, except mail." It commented:

If operations like the applicant's fall within the section, the Board in the light of the plain meaning of this language would have no alternative but to authorize applicant to engage in the transportation of passengers, if such a request were made. It would be absurd to attribute such an intention to Congress and such a result is entirely inconsistent with the general purposes of section 401 (e) as we understand them.

2 C.A.B. at 540-41. This latter ground for finding the grandfather clause inapplicable to indirect carriers is clearly inadequate. Section 401 (e) permits the Board to refuse a grandfather certificate to an applicant whose service during the prescribed period was "inadequate and inefficient." 52 Stat. 988 (1938). Surely an applicant whose air carriage service had been confined to express or freight forwarding would be found to have rendered "inadequate" service to qualify it for a grandfather certificate authorizing it to engage in passenger transportation. 
to REA would be in the public interest. ${ }^{49}$ In the other early forwarder decision, Universal Air Freight, 50 the Board denied an exemption to a surface carrier controlled forwarder without mentioning its surface affiliations.

The next air forwarder proceeding was in 1948, when the Board, believing that the admission of a substantial number of forwarders into air transportation would benefit the industry, ${ }^{51}$ consolidated the applications of 78 air forwarders seeking authorization to engage in air forwarding. ${ }^{52}$ In passing on REA's application for continued operating authority, the Board, for the first time, considered the relationship between REA and its railroad affiliations. It held that the relationship between REA and the railroads failed to bring section 408 directly into play because REA was wholly owned and controlled by the railroads before the passage of the Civil Aeronautics Act, and such ownership had not been extended or modified since its enactment. The Board cited Northeast Airlines and concluded that no section 408 issue could be raised as long as the ownership and control relationship remained unaltered.53 Although the grandfather clause had been found inapplicable to air forwarders, this reliance on Northeast is justifiable in light of the fact that in both cases the applicant had been engaged in pre-enactment full-blown air operations. ${ }^{54}$

49. 2 C.A.B. at 541. The exemption was from the requirement of $\$ 401$ (a) that an air carrier may not operate without a certificate. See note 5 supra and accompanying text. But certain provisions of the act, the Board commented, applied in terms to "air carriers," were nonetheless "obviously inapplicable" to air carriers of the indirect type. The proviso in $\S$ $1(2)$, it felt, clearly recognized this situation. Id. at 537.

The Board noted that an examination into the contracts between REA and the airlines was pending, and deferred until then further consideration of REA's operating authority. $I d$. at 541. But in the opinion in that case, Railway Express Agreements, 4 C.A.B. 157 (1943), nothing was said regarding the exemption under which REA was operating. Presumably the temporary exemption granted in the first CAB case involving REA, 2 C.A.B. 531 (1941), continued in effect until renewed in Air Freight Forwarder Case, 9 C.A.B. 473,489 (1948).

50. 3 C.A.B. 698 (1942). Universal Air Freight Corporation was the wholly owned subsidiary of United States Freight Corporation, whose other subsidiaries included surface forwarding companies, trucking and cartage companies and a warehousing company. United States Freight Corporation was controlled by Linden Securities Corporation, a holding company affiliated with the New York Central Railroad. See Air Freight Forwarder Case, 9 C.A.B. 473, 511 (1948) ; Moody's Industrial Manual 1348 (1939). The Board contended that air forwarding activities which had been carried on by Universal constituted engaging in air carriage, and charged that Universial had violated $\S 401$ (a) by failing to secure authorization. Universal requested that the $\mathrm{CAB}$ exempt it under $\$ 1(2)$. The Board found that Universal's business had been carried on at a loss and that respondent had not generated new traffic in sufficient volume so as to have any substantial effect on airline revenues. These observations led the Board to conclude that the public interest did not require exempting Universal. 3 C.A.B. at 707-08.

51. The Board, however, limited the exemptions granted under $\$ 1(2)-$ which was the mode of authorization selected by the Board in dealing with indirect air carriers-to five years. See 9 C.A.B. at 498.

52. Air Freight Forwarder Case, 9 C.A.B. 473 (1948).

53. Id. at 485 .

54. See text accompanying notes 35-36 supra and note 62 infra. REA's failure to secure a grandfather certificate was not because its pre-enactment operations were any less full 
The second proviso of section 408 was held not to be directly controlling. But the $\mathrm{CAB}$, in fact, considered the policy behind restricting surface carrier participation in air carriage in deciding whether to extend REA's exemption. The Board noted that some apprehension had been expressed that railroad ownership of REA might be inconsistent with the public interest and have an adverse effect on the development of potential air express services, but found such fears unwarranted in light of REA's past performances as an air express forwarder. ${ }^{55}$

The 1948 proceeding gave the Board further occasion to deal with questions of surface carrier participation in indirect air carriage. Several applicants were surface forwarders or surface forwarder subsidiaries (a surface forwarder functions in the same manner in relation to railroads, motor carriers, and water carriers as air forwarders do in relation to direct air carriers). With regard to surface forwarders applying for operating authorization in their own names, the Board asserted that it possessed discretion under American President Lines to weigh what it considered to be the policy of section 408(b)'s second proviso. Part of that policy was to ensure that surface transportation would not be promoted at the expense of air transportation. The CAB observed that participation in air freight forwarding by these surface forwarders would not be detrimental to the promotion of air operations, because surface forwarders, unlike the railroads, do not have substantial investments in transportation facilities to protect, and because the presence of competition among a large number of independent air freight forwarders would, in any case, deter the participating surface forwarders from diverting a substantial amount of traffic from air to surface transportation. Moreover, the CAB noted that the shipper, and not the forwarder, would generally stipulate the mode of transportation to be used. ${ }^{58} \mathrm{It}$ also considered whether entry by these surface forwarders would violate the antimonopoly policy of the first proviso of section 408(b).

Because of the number of independent air freight forwarders whom we are authorizing in this opinion to engage in air freight forwarding operations, we find further that the conduct of air freight forwarding operations by surface freight forwarders in question will not give rise to monopoly and thereby restrain competition or jeopardize any direct air carrier or any indirect air carrier. ${ }^{\mathrm{T}} \mathrm{T}$

The application of subsidiaries of surface forwarders afforded the Board an opportunity to re-examine the expansive view of an acquisition of control established in the Pan American decision. The Board responded by holding that the creeping control doctrine still applied to subsidiaries of surface carriers; but it also found that the air operations requirement of section 408's second proviso

blown than those of Northeast but only because REA was an indirect air carrier. See note 48 supra and accompanying text.

55. See 9 C.A.B. at 485 .

56. Id. at 502 .

57. Ibid. 
was not to be considered in air forwarder licensing proceedings, reasoning that the "use aircraft" language in that section referred only to direct air carriage. 58 Although the CAB's rather literal reading of the second proviso is questionable, the result of this interpretation is to treat subsidiaries of surface forwarders in the same manner as surface forwarders in entry proceedings. Thus, the discretionary policy of restricting surface carrier participation in air transportation and not the more rigid statutory test is the standard for entry into air forwarding whether the applicant is a surface carrier or a subsidiary of one.

The policy underlying the second proviso of section 408(b) was further applied in this proceeding to authorization requests of air forwarders controlled by motor carriers and railroad interests. Because of the limited investment of motor carriers in surface operations, and because of the usefulness of motor vehicles in gathering and distributing air cargo, the Board found that participation by trucking applicants in air forwarding operations would not result in a conflict of interest between air and surface carriage. ${ }^{69}$ Application of this reasoning, however, to railroad owned applicants led to the denial of operating authority or exemptions. The application of National Air Freight Forwarding Corporation, a subsidiary of a surface forwarder, which was controlled by the Chesapeake and Ohio Railway Company, the Pere Marquette Railway Company, and a subsidiary of the Erie Railroad Company, was denied because the Board believed that the railroads' large fixed investments in property and equipment not capable of being used in air services would be likely to furnish an incentive to strive for the development of rail business at the expense of "full and wholehearted" promotion of air transportation. Moreover, the Board thought that the use of railroad freight houses and extensive solicitation facilities would create a serious handicap to independent air freight forwarders seeking to compete for the business. ${ }^{60}$

58. Id. at 503. This holding was affirmed in American Airlines, Inc. v. CAB, 178 F.2d 903 (7th Cir. 1949).

59. 9 C.A.B. at 506-09.

60. Id. at 509-12. The Board also denied the application of Mississippi Valley Transportation Company, a wholly owned subsidiary of the Illinois Central Railroad, for the same reasons. The final applicant with railroad affiliation was Universal Air Freight Corporation, which had been denied entry in a prior case. See note 50 supra and accompanying text. In the 1948 proceeding, the Board found the record inconclusive as to Universal's relationship to other subsidiaries of its parent which were engaged in warehousing, package consolidation, and similar operations. Consequently, the Board dismissed Universal's application without prejudice.

In Air Freight Forwarder Case (International), 11 C.A.B. 182 (1949), the Board allowed these three rail controlled applicants to engage in international air freight forwarding. It observed that the railroad parents of these applicants were not engaged in foreign or overseas transportation. This fact was apparently viewed by the Board as indicating the unlikelihood of a conflict of interest arising which would result in the diversion of normal air traffic to surface transportation. In addition, the Board seemed to feel that the rail parents' size and the facilities available to the subsidiaries would not give these rail controlled applicants such competitive advantages as to present the dangers which the Board feared 
The rail controlled applicant appealed, alleging that the Board had acted arbitrarily and capriciously by denying it permission to operate while granting such authority to REA and the applicants controlled by motor carriers. Judge Bazelon, writing for the majority in National Air Freight Forwarding Corp. v. $C A B,{ }^{61}$ found that the Board's exemption of REA and the motor carrier applicants was distinguishable from its denial to the petitioner. REA had been engaged in substantial pre-enactment operations, which the Board was permitted to consider even though the grandfather clause did not apply. ${ }^{62}$

might accompany participation by rail controlled forwarders in domestic air freight forwarding.

61. 197 F.2d 384 (D.C. Cir. 1952).

62. The issue of $\S 408$ 's applicability to the control relationship between REA and its railroad parents illustrates the conceptual difficulties arising from the creeping control doctrine of Pan American and the Board's holding in the first REA case that $\$ 401$ (e), the grandfather clause, was inapplicable to indirect air carriers. Were REA granted continued operating authority in the 1948 proceeding, its parents would have no greater control over an air carrier than prior to the enactment of the Civil Aeronautics Act. On the other hand, the Board, by refusing to extend the exemption, could have deprived REA's railroad parents of control over an indirect air carrier subsidiary. Judge Bazelon, for the majority, emphasized the lack of increase in control which the grant to REA of continued operating authority would give its parents. He therefore found the Board's reliance on Northeast a proper reason for holding § 408 inapplicable to REA. See note 53 supra and accompanying text. Judge Prettyman, in dissent, stressed the fact that the Board was under no compulsion in the 1948 proceeding to grant an extension of REA's exemption.

The dissent urged that since the Board had earlier found REA outside the purview of the grandfather clause it could not now rely on the fact that REA had engaged in pre-enactment operations to avoid the applicability of $\$ 408$ under the Pan American doctrine. But the Northeast case, which held that $\S 408$ does not apply to an air carrier which had engaged in full-blown operations and which had been controlled by a surface carrier prior to the effective date of the act, placed no reliance on the grandfather clause. See notes 35-36 supra and accompanying text. Thus, it was not the fact that Northeast held a grandfather certificate which excused it from meeting the requirements of $\S 408$ but the fact of its pre-enactment operations. The only standard that the grandfather clause excused carriers such as Northeast from meeting was the public convenience and necessity test of $\S 401$ (d). REA's pre-enactment operations, which the Board held were not comprehended by the grandfather clause, while excusing it from meeting the requirements of $\S 408$, have not been the ground for excusing REA from meeting the public convenience and necessity test. Like all indirect air carriers, REA has not had to meet the standards of $\S 401$ (d) because of the Board's exempting power under $\S 1(2)$. To secure an exemption under $\$ 1(2)$, however, indirect air carriers, including REA, have had to satisfy that section's public interest test. See note 44 supra and accompanying text.

In assessing the public interest, both in the case of REA and of the appellant, National Air Freight Forwarding Corp., the $\mathrm{CAB}$ considered the policy ascribed to the surface carrier proviso of $\S 408$. Even if $\S 408$ had been held applicable to REA, the Board's decision that the terms of the second proviso were inapplicable to air forwarders would have precluded a consideration of anything more than that proviso's policy. In REA's case, the Board found the policy behind the surface carrier proviso outweighed by REA's record of good performance in promoting air express forwarding and by the fact that REA's operations pre-dated the Civil Aeronautics Act. In National's case, the policy of the restrictive proviso was not outweighed by either good past performance or pre-enactment operations. Thus, the treatment of REA and National, under the public interest test of $\S 1(2)$, are distinguishable. 
Moreover, REA's past record in promoting air express justified the conclusion that the control relationship between $\mathrm{REA}$ and its railroad parents would not detrimentally affect REA's air forwarding operations. National further argued that two factors considered by the Board in allowing motor carriers participation in air freight forwarding were equally pertinent to rail carriers, noting the Board's assertion that competition of a large number of independent air freight forwarders would deter the participating surface forwarders from diverting any substantial amount of traffic from air to surface transportation, and that the shipper, and not the forwarder, would generally designate the means of transportation to be used. Although the court apparently agreed with National on this point, it found that the Board's distinction between motor carrier control and railroad control, based upon the difference in surface investment of the two, was sufficient to justify a denial to National. ${ }^{63}$

Judge Prettyman's dissent in National Air Freight Forwarding Corp. $v$. $C A B$ represents the first elaborate application of the economic reasons for restricting surface carrier participation in air carriage to a particular surface carrier requesting operating authority. Judge Prettyman compared National's relative capacity to divert normal air freight traffic to its rail operations with REA's capacity to divert air express to its surface operations :

[I]n the forwarding of air freight there will be some fifty competitors, whereas in the air express business there will be none. If the railroads should press for the shipment of express by rail instead of by air, the pressure would be effective, because their subsidiary is the only express forwarding agency. But if the railroad controlling one out of fifty-some freight forwarders tried to divert air business to rail movement, it would seem to me that the other competing air freight forwarders, who offer the service the shipper wants, would very quickly take over the business. Diversion from one hand to the other of the same railroad-owned monopoly is one thing, but diversion in the face of a large group of active competitors is something else. ${ }^{64}$

Judge Prettyman also thought more emphasis should have been given to the two factors which were significant in the authorization of the motor carriers,

The question to which the D.C. Circuit should have addressed itself, but which neither the majority nor the dissent directly answered, was whether the distinction satisfies a standard of reasonableness such that the Board's action could not be reversed as arbitrary and capricious.

63. See 197 F.2d at 390.

64. Id. at 392. The CAB had distinguished between "express" and "freight" forwarding, observing that the image of express service, with its emphasis on speed-which originated in rail transportation where the express business had its inception as a personalized service operating at premium rates over the faster and more dependable schedules of passenger trains-persisted in the minds of the shipping public. 9 C.A.B. at 488 . But see Wilson, Air Freight and Air Express, 15 Law \& Contemp. Prob. 37 (1950).

65. Judge Prettyman's conception of the proper role of the competition factor is indicated in the text accompanying note 64 supra. He also regarded surface freight service and air freight service as "totally dissimilar." "Common sense" suggested that competition between them was highly improbable. The dissent concluded that the shipper who wished his goods to move by air could rarely be persuaded to have them carried by rail. 197 F.2d at 392 . 
but, in arguing that forwarders with motor connections were no more deservant of authorization than National, he ignored the difference in relative surface investment of such carriers.

By 1955 the Board was prepared to employ a more empirical analysis and take a closer look at the alleged dangers of surface carrier participation in air freight forwarding. This time, basing its decision on the virtues of competition, the Board granted National an exemption. ${ }^{66}$ Acknowledging that National and another rail controlled applicant would possess some competitive advantages because of their railroad parentage and their pre-eminence in surface freight forwarding, the $\mathrm{CAB}$ stated that the possibility of public detriment from these factors would be countered by several vigorous, successful air forwarders which had developed since 1948. The Board was unimpressed by the evils which would allegedly result from surface carrier participation. Protestants at the hearing argued that the railroad parents would use their air freight subsidiaries to destroy independent forwarders by offering "unreasonably low" rates and that the Board proceedings aimed at correcting such rates on complaint of an individual forwarder would prove too lengthy and expensive to be an adequate remedy. In rejecting these arguments, the Board suggested that should National engage in rate cutting which seriously endangered the survival of independent forwarders, it would be challenged by more than a single forwarder or by the Board's staff or both. Furthermore, the Board noted that the encouragement of lower rates would be in the public interest and believed that this consideration outweighed what it termed "a very limited risk of destructive rate competition." As to traffic diversion, the Board agreed with the examiner that the railroads who controlled these applicants would have more incentive to dissuade shippers from using air freight service if their requests for authorization were repeatedly refused than if they. were granted. The Board conceded that the promotional efforts of these applicants might not be carried on in a vigorous manner, but pointed out that their services as air freight forwarders would become available to their numerous surface customers, thereby increasing the overall use of air freight forwarder service. Moreover, the Board observed the particular contribution which Universal and National could make toward stimulating the growth and effectiveness of air freight services:

In the cases of these two applicants, we also note that the introduction into air-freight forwarding of organizations having extensive experience and facilities in the field of surface freight may result in the adaptation and introduction into air-freight of practices or techniques which contribute to the attractiveness of the service or the efficiency with which it can be rendered. ${ }^{68}$

66. Airfreight Forwarder Investigation, 21 C.A.B. 536, 544-46 (1955). Universal Air Freight, see notes $50 \& 60$ supra, also applied for and received operating authority.

67. 21 C.A.B. at 545.

68. Id. at 546 . 
In $R E A$, Airfreight Forwarder Application, ${ }^{69}$ a recent air forwarder proceeding, REA requested authorization to operate as an international air freight forwarder. The market that REA was attempting to enter was strictly that of nondomestic air freight forwarding. ${ }^{70}$ Because of the organization which it had developed to service the domestic, small shipments field, the Board, accepting the findings of the examiner, found that REA could provide a useful new service and noted that REA's comprehensive transportation services, not available elsewhere on the same scale, put it in a position to generate new international cargo. International air freight forwarding authority for REA, in combination with its existing nationwide facilities, would clearly provide wider solicitation coverage, faster service, and other advantages of integrated rail-air service resources. But these very characteristics which would enable $R E A$ to provide a useful new service, according to the $C A B$, would also give it an undue competitive advantage resulting in dominance or monopolization of international air freight forwarding. ${ }^{71}$ It was found that since many of REA's domestic shippers also had a need for international air forwarding services, the very fact of prior association with these shippers would give REA a substantial advantage over the other international air freight forwarders. Moreover, if REA's contention that many shippers then using its services on the domestic leg of their international shipments would prefer to employ one transportation company for all their international shipping needs rather than utilize multicarrier arrangements were true, REA would, if allowed to enter, be the only transportation company able to offer these shippers this unitary, superior service. ${ }^{72}$ For these reasons, the Board concluded that REA's dominant position in the domestic, small shipments market would give it a strategic advantage in obtaining a powerful position in international air freight forwarding, and therefore refused to authorize such operations. ${ }^{73}$

The examiner also found another major objection to granting authorization to REA. That objection was to an admitted attempt by REA to divert traffic on the domestic leg of international shipments to rail express by engaging in rate competition against air freight forwarders. ${ }^{74}$ At the time of its

69. 27 C.A.B. 500 (1958).

70. Id, at 506. The domestic aspects of international air forwarding include consolidating shipments and/or breaking bulk at domestic points other than gateway cities-i.c., cities which are the final points of departure from the United States or the first points of arrival from overseas or foreign areas. REA did not request authority to perform these domestic functions.

71. Id. at 535 .

72. Because a number of air freight forwarders operate in both the domestic and international markets, they would seem to be in a position to compete with REA for this business. For example, a Toledo manufacturer, interested primarily in saving time in the transit of his shipments, supported REA's application because of the availability to him of REA's pickup and delivery service at Toledo. $I d$. at 521 . There would seem no reason why the air freight forwarders could not develop speedy pickup and delivery services of their own to compete for traffic demanding such handling.

73. See $i d$. at 501 .

74. Id. at 512-13. 
application REA had filed a tariff with the Interstate Commerce Commission which proposed substantial rate reductions for domestic rail express service of international shipments. If REA were allowed to consolidate air freight in the port cities, it could offer shippers not only a lower rate on the domestic segment of the operation but also a one transportation company service for the forwardering operations. Since REA's rail rates were not under the jurisdiction of the CAB, the Board could not prevent "destructive" and "unfair" competition between REA and other international air freight forwarders. ${ }^{75}$

Since the Board has never treated the second proviso of section 408 (b) as a controlling standard in forwarder cases, its experience in this area affords an opportunity to observe the factors considered relevant in determining whether entry by any particular surface carrier will promote or inhibit the policies of the act. Prior to the 1948 proceeding on domestic forwarding, the Board disposed of cases involving REA and Universal Air Freight Corporation with little, if any, regard to their surface affiliations. Beginning in 1948, however, the Board explicitly and directly dealt with the issue of surface carrier participation. The most determinative consideration was the likelihood of a particular applicant's surface connections affording it an "undue" competitive advantage over other air forwarders or leading it to promote surface business at the expense of air forwarding. Elements which the Board weighed in favor of permitting air forwarding operations by surface affiliated applicants included the fact that the applicant had displayed a willingness and ability to promote and encourage air traffic, ${ }^{76}$ that the applicant would face a large number of competitors in air forwarding, 77 and that the applicant had a relatively low investment in surface facilities. ${ }^{78}$ Moreover, the Board looked to whether shippers desiring to utilize air services would be unlikely to transfer their business to surface carriage, ${ }^{79}$ whether the operations of the surface parent were

75. In American Express Company, Docket No. 9315 (CAB May 10, 1960) aff'g Examiner's Recommended Decision (Sept. 30, 1959), protestants to the applicant's request for international air freight forwarding authority suggested the possibility that Amexco, the applicant, might misuse its banking connections to promote its proposed air forwarding service. They contended that through flexible interest rates on deposits and lower commission rates on letters of credit, Amexco would be in a position to grant rebates to forwarding customers. The examiner discounted the likelihood of destructive competition in the air freight forwarding business, noting the highly competitive nature of the industry, its low entry costs (in terms of capital outlay), and its generally narrow profit margins. $\mathrm{He}$ surmised:

Amexco still is in business to make money. It is inconceivable that they would cut profits on existing enterprises to obtain a foothold in a highly competitive business where the only assurance of maintaining that foothold would be at the continued expense of its other profitable enterprises.

Examiner's Decision at 29. One may wonder why similar sentiments should not have disposed the CAB to be unconcerned about REA's rate cutting on rail express shipments moving in international commerce.

76. See note 55 supra and accompanying text.

77. See note $\mathbf{5 6}$ supra and accompanying text.

78. See ibid.

79. See ibid. 
geographically separate from the area of an applicant's proposed air operations, ${ }^{80}$ and whether the Board would possess power to prevent neglect of air operations or destructive competition subsequent to entry. ${ }^{81}$ The absence or obverse of some or all of these factors resulted in a denial of the application.

\section{Toward a Discretionary Approach}

The Board's approach in the forwarder cases-that of weighing various considerations in determining the propriety of entry into indirect air carriage by surface carrier affiliates-suggests a workable alternative to the "controlling standard " treatment afforded to the second proviso in direct carrier cases. A1though the $\mathrm{CAB}$ has discretion to undertake a multifactoral approach in all cases in which the applicant is a forwarder, where the applicant requests authorization for direct air carriage, the Board may only employ this approach if the applicant is a surface carrier applying for a certificate in its own name..$^{82}$ Where the applicant seeking entry into direct air carriage is a subsidiary of a surface carrier, the Board is compelled by the Pan American doctrine to apply the second proviso as a controlling standard. ${ }^{83}$ Were Pan American reversed, the Board would be able to utilize the suggested "discretionary" approach in all cases in which the surface carrier seeks to "build" into air transportation. The rationale for reversing Pan American is the "buildingbuying" distinction which is suggested by the terms and structure of the statute. ${ }^{84}$ Once it is determined that the creation of a subsidiary is not an "acquisition," section 408 is not triggered in a section 401 proceeding and the second proviso is no longer controlling. The Board would then be free to consider the policy ascribed to the second proviso in the course of applying the recommended multifactoral approach. This approach would better enable the Board to promote the policies of the act. Treating the second proviso as controlling in licensing proceedings prohibits entry by surface carriers in many cases in which such entry would result in "encouragement and development" of air transportation, "promotion of adequate, economical, and efficient service by air carriers at reasonable charges," and "competition to the extent necessary to assure the sound development" of the air industry. ${ }^{85}$ For instance, steamship companies possessing a familiarity with world trade which might be utilized to aid expansion of United States air commerce ${ }^{86}$ are automatically barred from air operations when section 408 is directly applied. The same is true for surface carriers possessing facilities and agents which could be employed in air transportation, thereby leading to economies of operation. ${ }^{87}$ Such

80. See note 60 supra.

81. See text accompanying notes $66-67$ supra.

82. See notes 38-39 supra and accompanying text.

83. See note 25 supra and accompanying text.

84. See notes 31-33 supra and accompanying text.

85. See $\$ 2,52$ Stat. 980 (1938), 49 U.S.C. § 1302 (1958).

86. See American President Lines, $\nabla$ C.A.B. 799, 808 (1947) (Chairman Landis, concurring).

87. Ibid. 
economies, when passed on to shippers and passengers through better service and lower rates, would stimulate and enhance use of air carriage. Moreover, surface carriers may be the most effective and perhaps, in some instances, the only source of new competition to existing air carriers. ${ }^{88}$ Because of these potential advantages, it would seem appropriate for the Board, in any particular case, to ascertain whether the alleged evils of surface carrier participation are actually present and to weigh the existence of such evils, where found, against the probable benefits which would result from entry.

One of the evils alleged to result from surface carrier participation in air transportation is that:

by reason of their superior resources and extensive facilities for solicitation, such carriers would often be the possessors of powerful competitive weapons which would enable them to crush the competition of independent air carriers. ${ }^{80}$

The presumption that entry by a carrier with strong surface affiliations is likely to interfere with attaining the objectives of the act is highly questionable. It will be recalled that, in the 1948 proceeding involving domestic air freight forwarding, the Board excluded rail controlled applicants because it feared that they would be in a position to employ their parents' facilities to the detriment of other air forwarders. ${ }^{00}$ But in 1955, the Board observed that several vigorous, successful forwarder enterprises had since developed. ${ }^{91}$ The Board seemed to find that several of these competitors were no longer "infants," in need of protection, but were sufficiently "mature" to provide the competitive check needed to ensure that the participation of railroad subsidiaries would be beneficial to air freight forwarding. Thus, rail affiliated applicants which previously had been denied entry were authorized. The present state of development of the direct air carriage industry would seem to render the Board's 1955 performance more pertinent than its action in 1948. For as one article on new carrier entry has concluded:

The growth of air transportation and its current strength is one of the very reasons why entry by new carriers would involve no impairment of the operation of the older carriers. ${ }^{92}$

88. The present situation in British aviation suggests that shipping interests will most likely be a potential source of competition against established air carriers. The Civil Aviation (Licensing) Act, 1960, 8 \& 9 Eliz. 2 c. 38, was passed as part of the Conservatives' policy to encourage competition on the part of British "independents" against the "corporations"Britain's two nationalized airlines, British Overseas Airways Corporation (BOAC) and British European Airways (BEA) - which until then had been the "chosen instruments" of British air transport. In this particular attempt to secure new competition, surface carrier affiliates were the principal source, since ocean shipping interests are the prime owners of Britain's two major independent airlines. See Aviation Week, May 22, 1961, pp. 34-35.

89. American President Lines, 7 C.A.B. 799, 803 (1947).

90. See note 60 supra and accompanying text.

91. See note 66 supra and accompanying text.

92. Maclay and Burt, Entry of New Carriers into Domestic Trunkline Air Transportation, 22 J. AIR L. \& Com. 131, 151 (1955). 
With regard to the argument that an applicant's surface connections will give it a competitive advantage over other air carriers, several comments seem warranted. Frequently such a statement is an assertion rather than a finding. Since a new entrant is often at a disadvantage to existing competitors, it should not be presumed that surface carrier parentage will do any more than equalize the competitive abilities of new and existing competitors. Furthermore, to the extent that the surface affiliated entrant has an advantage based upon its superior efficiency, entrance would seem warranted by the statutory mândate instructing the Board to promote "adequate, economical, and efficient service" and to encourage "competition to the extent necessary to assure the sound development" of air transportation. Finally, should the entrant in fact engage in rate cutting which the Board considers "destructive competition," the Board's power to establish minimum rates seems adequate to prevent such practices. ${ }^{93}$

Another charge levelled against surface carrier participation is that a conflict of interest would develop between the promotion of air and surface services. ${ }^{94}$ This charge is directed at both a sin of omission and of commission. The passive danger is that a surface controlled air carrier will not vigorously promote air transportation; the active one is that the surface parent will use its air subsidiary to "divert" normal air traffic to its surface operations. The fear that an entrant with substantial investment in surface facilities will fail to promote air service seems chimerical as well as contradictory of the Board's contention that air carriers with extensive surface resources will compete so vigorously that independent air carriers will be driven from markets which they already serve. Relative investment is not a meaningful criterion for determining whether an applicant's surface connections will impair the vigor of its air carriage promotion. ${ }^{95}$ Once a firm has made its fixed investments, it will devote its variable resources to the employment which secures the greatest return on such resources. So long as air carriage brings a greater return per additional dollar of expenditure than surface carriage, a firm should continue to expend available funds for the promotion of the former. Where an applicant's affiliated surface operations are in a market geographically separate from that of its proposed air operations or the air service is found to be in a different line of commerce from the surface operations, ${ }^{96}$ utilization of variable

93. See $\$ 403,52$ Stat. 992 (1938), 49 U.S.C. $\$ 1373$ (1958).

94. American President Lines, 7 C.A.B. 799, 803 (1947):

Surface carriers engaging in air transportation would at times be under a strong incentive to act for protection of their investment in surface transportation interests.

95. Even if comparative surface-air investment were a proper indicium of the probable extent of air carriage promotion, direct air operations require substantial capital investment. Under the present interpretation of $\S 408$ (b), which applies to direct air carriers seeking entry by real or paper acquisitions, the Board is not even afforded the discretion to consider the relative air-surface investment. The presumption is that surface carrier participation in air operations will violate the policies of the act.

96. American Export Airlines and its parent, Steamship Company, operated in neither the same geographical market nor the same line of commerce. Airlines held a certificate for 
resources for the purposes of promoting air traffic will be detrimental to its surface operations only to the extent that such funds might have been employed in the promotion of surface traffic. Where, however, the air and surface operations are in the same geographical market and are fungible, the promotion of air service may actually divert existing traffic from a company's surface facilities to its air facilities. Whether this situation will in fact inhibit the promotion of air traffic should depend on the relative, anticipated profit yields from the two types of service. Thus, the criteria which the Board should consider in determining the importance of conflicting interests are the expected profits from air and surface operations in the market for which the applicant seeks authority. The fear of actual diversion of traffic from air to surface operations also seems unrealistic, for it is difficult to see why a surface carrier would be more likely to attempt such diversion after it invested in air facilities than prior to such investment. Indeed, the Board has argued persuasively that surface carriers have greater incentive to divert air traffic when applicants which they control are refused authorization than when permission is granted. ${ }^{97}$

These observations strongly suggest that a presumption against granting surface carriers authority to engage in air operations is unwarranted. The objectives of the act would best be advanced if the Board examined the probable consequences of entry in the light of the relevant circumstances of each case. Relevant considerations suggested by this Comment include the number and strength of competitors already serving the market which the surface carrier seeks to enter, the geographical overlap of the surface carrier's operations with the proposed air service, the extent to which the surface and air operations are considered interchangeable by passengers and shippers, and the relative expected profits of the applicant's air and surface operations. The past performance in air or surface carriage of a surface affiliated applicant or its parent should also be considered as an aid to predicting future conduct. Absent a finding that entry will be detrimental to air carriage, participation in air

service between New York and Lisbon, Portugal, not being operated, and was engaged in air transportation between New York and Foynes, Ireland. American Export Airlines, Inc., 3 C.A.B. 619 , at $620-21$. The Board noted on reargument:

Steamship Company is primarily a freight carrier and has never operated to any port in the British Isles, and prior to the present war it made only an occasional stop at Lisbon on westbound voyages.

American Export Lines, 4 C.A.B. 104, at 108. Further, Member Ryan, in a concurring opinion, insisted that Steamship Company, having found the cost of luxury liners prohibitive, resorted to the alternative plan of entering transatlantic air carriage, and concluded:

It is contemplated that the luxury passenger traffic will travel by air, while the remaining passenger traffic and freight will be handled by the modernized passenger and cargo fleet which Steamship Company intends to acquire. Thus, each enterprise will seek a different class of traffic.

3 C.A.B. at $629-30$.

97. See Airfreight Forwarder Investigation, 21 C.A.B. 536, 546 (1955). For discussion of this case, see text accompanying notes 66-68 supra. 
transportation by a surface carrier controlled applicant should not be precluded merely because of the applicant's parentage..$^{98}$

The desire of surface carriers to sprout wings is understandable; it undoubtedly stems from an acute awareness of the trends in transportation. In 1960, for example, more than twice as many travelers chose to cross the Atlantic via a six-hour jet flight than a five-day ocean voyage. Further, the number of those flying in 1960 marked a 25 per cent gain over the number choosing that mode of crossing in 1959.99 A multifactoral approach would remove artificial legal barriers to entry by surface carriers and thereby permit some of their resources-especially their solicitation systems and the talent gained from their experience in transporting goods and people-to be converted from modes of surface carriage to the expanding enterprise of air transportation.

98. On March 10, 1959, Senator John M. Butler, at the request of the railroad industry, introduced a bill calling for the removal of the restrictions which currently exist on surface carrier participation in air transportation. S. 1354, 86th Cong., 1st Sess. (1959). The first section of the bill would have disallowed the CAB to apply any "special or different standards, requirements, or burden of proof," or to attach or prescribe any terms, conditions, or limitations "merely by reason of the fact that a person affected by such a proceeding, whether as an applicant or otherwise" is or is controlled by or affiliated with a carrier other than an air carrier. The second section of the bill would have repealed the second proviso of $\S 408$ (b). Were this bill enacted, the multifactoral approach, advocated in this Comment for entry cases, could be applied in merger or acquisition cases as well.

99. Newsweek, June 19, 1961, pp. 76-77. 